\title{
Changes in cell morphology and carnitine acetyltransferase activity in Candida albicans following growth on lipids and serum and after in vivo incubation in mice
}

\author{
Rose Sheridan $\uparrow$ and Colin Ratledge
}

Department of Biological Sciences, University of Hull, Hull HU6 7RX, UK

\author{
Author for correspondence: Colin Ratledge. Tel: +44 1482 465243. Fax: +44 1482465458. \\ e-mail: c.ratledge@biosci.hull.ac.uk
}

\begin{abstract}
Candida albicans C316, maintained in the yeast form, showed a proliferation of peroxisomes when grown on triolein or serum as sole carbon source but these structures were absent from glucose-grown cells. Peroxisomes were also apparent in C. albicans obtained after injection into mice and recovery from intraperitoneal washings and kidneys; they may therefore be useful markers to assess a potential in vivo response in cells that are growing in vitro. Transcell-wall structures also occurred in C. albicans grown on triolein or serum, and in cells cultured in vivo, but were not seen in cells grown on glucose. These structures consisted of electron-dense fibrillar material penetrating through the cell wall from the plasmalemma side and protruded out to the exterior of the cell. Endoplasmic reticulum, located at the periphery of the cell, was found to be in close proximity with these cell wall structures. Carnitine acetyltransferase (CAT; EC 2.3.1.7), the key enzyme for the translocation of acetyl units between intracellular compartments, was present in low activities in glucose-grown cells; its activity was increased some 100-fold in trioleingrown cells but only 4-fold in serum-grown cells. It was not possible to assess this activity in the in vivo-cultured cells. Two separate CAT proteins, partially purifed from isolated microchondria and peroxisomes, respectively, were identified, with different specificities and kinetic properties.
\end{abstract}

Keywords: Candida albicans, carnitine acetyltransferase, lipid, mitochondrion, peroxisome

\section{INTRODUCTION}

The phenotypic switch between yeast and hyphal form, thought to be involved in increased adherence and host tissue invasion in vivo (see Odds, 1988), has been observed in pathogenic Candida species grown on substrates as apparently diverse as hydrocarbons and serum. Fukui's group found that $C$. tropicalis grown on n-alkanes often grew in the filamentous form (Yamamura et al., 1975; Hirai et al., 1972) and Hitchcock et al. (1989), Gow \& Gooday (1984) and Shepherd et al. (1980) have found that serum is consistently effective in the induction of germtube formation and hyphal growth with $C$. albicans.

\footnotetext{
† Present address: The Advanced Centre for Biochemical Engineering,
} University College London, Torrington Place, London WC1E 7JE, UK.

Abbreviations: CAT, carnitine acetyltransferase; IP, intraperitoneal; TCA, tricarboxylic acid.
The relationship between $\mathrm{pH}$, temperature and the morphology of $C$. albicans has also been exploited to study yeast and filamentous forms without changing major components of the medium (Prasad, 1987). Yet, even if the morphology is maintained, the nutritional status of the yeast must elicit changes in its ultrastructure. Compartmentalization and subcellular localization of enzymes appear to play a crucial role in control of metabolite pool sizes, substrate cycling and flux through metabolic pathways (Crabtree et al., 1990; Sumegi et al., 1990; Srere et al., 1990) and can vary according to the growth substrate being used by the yeast (for examples see Veenhuis \& Harder, 1987, 1991). Similarly, as we record here, a complex physical and nutritional environment in vivo can also elicit extreme intracellular and morphological changes in C. albicans C316, and consequently, we have investigated the contribution that complex carbon sources, such as lipid and serum proteins, may have in inducing similar morphological changes in vitro. For 
example, the appearance of peroxisomes is engendered by growing the cells on triolein and serum. Triolein is degraded by the organism via the $\beta$-oxidation cycle, the enzymes of which are located wholly within the peroxisomes (Tanaka \& Fukui, 1989; Veenhuis \& Harder, 1991) and, similarly, many of the amino acids derived from serum are also handled in the peroxisomes. A common feature of degradative pathways in the peroxisomes is their linkage to catalase/peroxidase and also to the formation of acetyl-CoA. In C. albicans, the subsequent movement of acetyl-CoA out of the peroxisome, as well as its possible entry into or exit from the mitochondrion, relies entirely on carnitine acetyltransferase (CAT; EC 2.3.1.7) (Sheridan et al., 1990). We have therefore studied the appearance of this activity in the different cells grown in vitro. We consider that the results may provide useful indicators as to the likely metabolic status of this pathogenic yeast when growing in host tissues.

\section{METHODS}

Yeast and growth. Candida albicans C316 (a clinical isolate) was supplied by Dr Peter Chalk, Glaxo-Wellcome Research Ltd, Stevenage, UK. The culture was maintained on yeast extract/ malt extract/glucose (YMG) slopes, stored at $4{ }^{\circ} \mathrm{C}$. It was grown on a basal medium containing ( $\mathrm{g} \mathrm{l}^{-1}$ distilled water): $\mathrm{KH}_{2} \mathrm{PO}_{4}, 4 \cdot 75 ; \mathrm{Na}_{2} \mathrm{HPO}_{4}, 2 \cdot 1 ; \mathrm{MgSO}_{4} .7 \mathrm{H}_{2} \mathrm{O}, 0.5 ;$ yeast extract (Difco), $0.1 ; \quad \mathrm{CaCl}_{2} .2 \mathrm{H}_{2} \mathrm{O}, 0.1 ; \mathrm{FeSO}_{4} .6 \mathrm{H}_{2} \mathrm{O}, 0.008$; $\mathrm{ZnSO}_{4} .7 \mathrm{H}_{2} \mathrm{O}, 0.001 ; \mathrm{MnSO}_{4} .4 \mathrm{H}_{2} \mathrm{O}, 0.001 ; \mathrm{CuSO}_{4} .5 \mathrm{H}_{2} \mathrm{O}$, 0.005 and diammonium tartrate, 3 , with the $\mathrm{pH}$ adjusted to 5.5 . Either glucose at $56 \mathrm{mM}$, triolein (commercial trioleoylglycerol) at $2.5 \mathrm{mM}$ or foetal bovine serum (Sigma) at $10 \%(\mathrm{v} / \mathrm{v})$ was added as carbon source. To ensure that $C$. albicans $\mathrm{C} 316$ was adapted to each medium, the cells were subcultured twice on the supplemented medium. Cultures were grown at $30^{\circ} \mathrm{C}$ as $100 \mathrm{ml}$ batch cultures in $250 \mathrm{ml}$ Erlenmeyer flasks on a gyroratory shaker operating at 180 cycles $\mathrm{min}^{-1}$. Cells were harvested by centrifugation $\left(5000 \mathrm{~g}, 10 \mathrm{~min}, 4^{\circ} \mathrm{C}\right)$, washed in distilled water and prepared for electron microscopy.

\section{Animal models}

Intraperitoneal (IP) washings and kidneys were taken from female Charles River, Harefield strain (CR-H) albino mice.

IP washings. Each of 20 mice received $0.1 \mathrm{ml}$ yeast culture intraperitoneally, receiving $4 \times 10^{7}$ c.f.u. of $C$. albicans C316 at time zero. At $6 \mathrm{~h}$ post-infection, 10 animals were killed and the peritoneum washed out with $4 \mathrm{ml}$ saline to remove the yeast cells. Samples were centrifuged at $3000 \mathrm{~g}$ for $5 \mathrm{~min}$ and resuspended in $1 \mathrm{ml}$ saline. The samples were kept at $-80^{\circ} \mathrm{C}$ until required for electron microscopy.

Kidneys. Seven mice were injected intravenously with $8 \times 10^{5}$ blastospores of $C$. albicans C316. At $24 \mathrm{~h}$ post-infection, both kidneys from each mouse were removed and kept at $-80^{\circ} \mathrm{C}$ until required for electron microscopy. One kidney from each of two mice was homogenized in a tissue grinder for viable counts giving an average of $3.5 \times 10^{3}$ cells per kidney. The yeast cells were extracted from the kidney using a method based on a World Health Organization process for purification of Myobacterium leprae (WHO, 1980). Chopped thawed kidney tissue was homogenized in a Potter-Elvehjem glass homogenizer with $0.14 \mathrm{M} \mathrm{NaCl} / 0.2 \mathrm{M}$ Tris base $/ 1 \mathrm{mM} \mathrm{MgSO}_{4}$ at $4 \mathrm{ml}$ per $\mathrm{g}$ tissue. The homogenate was centrifuged $(10000 \mathrm{~g}, 10 \mathrm{~min}$, $4{ }^{\circ} \mathrm{C}$ ), the supernatant discarded and the pellet re-homogenized, and the process repeated. The pellet was finally resuspended in washing buffer $(0 \cdot 14 \mathrm{M} \mathrm{NaCl} / 0 \cdot 015 \mathrm{M}$ HEPES, $\mathrm{pH} 7 \cdot 2,1 \mathrm{mM}$ $\mathrm{MgSO}_{4} / 0 \cdot 1 \%$ Tween 80 ) and the above process repeated twice. The final pellet was resuspended in DNase buffer $(0.1 \%$ Tween $80 / 1 \mathrm{mM} \mathrm{MgSO}_{4} / 0.03 \mathrm{M}$ HEPES, pH 7.2, with 4 units DNase $\mathrm{ml}^{-1}$ ) at $4 \mathrm{ml}$ per $\mathrm{g}$ of original tissue and incubated at $20^{\circ} \mathrm{C}$ for $30 \mathrm{~min}$, with stirring. The suspension was filtered through a strainer with $\sim 0.5 \mathrm{~mm}$ stainless steel mesh to remove connective tissue. The suspension was centrifuged $(10000 \mathrm{~g}$, $10 \mathrm{~min}, 4^{\circ} \mathrm{C}$ ) and the resulting pellet resuspended in buffered Tween 80 (as for DNase buffer minus DNase) at $4 \mathrm{ml}$ per $\mathrm{g}$ original tissue. This suspension was made $30 \%(\mathrm{v} / \mathrm{v})$ with Percoll and was distributed to $25 \mathrm{ml}, 27 \mathrm{~mm}$ diameter tubes and centrifuged $\left(27000 \mathrm{~g}, 45 \mathrm{~min}, 4^{\circ} \mathrm{C}\right)$, in a fixed-angle rotor. The tissue-derived debris remained as a distinct band at the top of the tube and the candidal band at the bottom. The yeast band was removed and washed in saline to remove the Percoll prior to electron microscopy.

Electron microscopy. Harvested washed yeast cells, pelleted yeast from IP washings and yeast obtained from kidney tissue were treated essentially as described by Holdsworth et al. (1988). The cells were fixed with $\mathrm{KMnO}_{4}(1.5 \%$, w/v) for $20 \mathrm{~min}$ at room temperature, washed twice in distilled water and poststained with uranyl acetate $(1 \%, \mathrm{w} / \mathrm{v}$, in water) for $3 \mathrm{~h}$. They were dehydrated in a graded ethanol series and embedded in Epon 812/Araldite. The embedded material was cut with diamond or glass knives on a Huxley mark I ultramicrotome. Sections were mounted on 100 mesh Formvar-coated copper grids and viewed on a JEOL JEM 100c transmission electron microscope at $80 \mathrm{kV}$. Representative sections of the whole area were recorded.

Subcellular fractionation. Spheroplasts were obtained after DeLaissé et al. (1981), harvested $\left(1000 \mathrm{~g}, 10 \mathrm{~min}, 4^{\circ} \mathrm{C}\right)$ and washed once in $1.2 \mathrm{M}$ sorbitol. The spheroplasts were resuspended in $10 \mathrm{mM}$ Tris $/ \mathrm{HCl}(\mathrm{pH} \mathrm{7.5)}$ containing $0.6 \mathrm{M}$ sorbitol and $1 \mathrm{mM}$ EDTA. The suspension was hand-homogenized in a Potter-Elvehjem glass homogenizer using a maximum of 10 passes. The cell debris $\left(P_{1}\right)$ was removed by centrifugation $\left(3000 \mathrm{~g}, 10 \mathrm{~min}, 4^{\circ} \mathrm{C}\right)$. The supernatant $\left(\mathrm{S}_{1}\right)$ was centrifuged at $20000 \mathrm{~g}\left(15 \mathrm{~min}, 4^{\circ} \mathrm{C}\right)$ to obtain the particle fraction $\left(\mathrm{P}_{2}\right)$ containing peroxisomes and mitochondria. The pellet $\left(\mathrm{P}_{2}\right)$ was resuspended in $10 \mathrm{mM}$ Tris $/ \mathrm{HCl}(\mathrm{pH} 7.5)$ containing $0.8 \mathrm{M}$ sucrose, $1 \mathrm{mM}$ EDTA, $0.1 \% \mathrm{BSA}$ and loaded on to a discontinuous density gradient of $25-55 \%(\mathrm{w} / \mathrm{v})$ sucrose (Ueda et al., 1982) to separate peroxisomes and mitochondria $\left(50000 \mathrm{~g}, 3 \mathrm{~h}, 4^{\circ} \mathrm{C}\right)$. The peroxisomal and mitochondrial bands were removed using a Pasteur pipette with the tip bent at a $90^{\circ}$ angle.

Column chromatography. CAT was partially purified from crude cell extracts or isolated mitochondria and peroxisomes.

Washed cells suspended in $100 \mathrm{mM}$ Tris/HCl (pH 8.0), $5 \mathrm{mM}$ EDTA, $1 \mathrm{mM}$ benzamidine, $0 \cdot 2 \mathrm{mM}$ PMSF, $1 \mathrm{mM}$ DDT were disrupted by two passes through a French press $\left(4^{\circ} \mathrm{C}, 35 \mathrm{MPa}\right)$. The supernatant (retrieved after centrifugation, $48000 \mathrm{~g}$, $30 \mathrm{~min}, 4^{\circ} \mathrm{C}$ ) was taken up to $1 \%$ Triton $\mathrm{X}-100 / 50 \mathrm{mM} \mathrm{KCl}$ and CAT was solubilized for $18 \mathrm{~h}$ at $4{ }^{\circ} \mathrm{C}$. Two ammonium sulphate fractions, at $30 \%$ and $65 \%$ saturation, were taken. The $65 \%$ pellet $\left(18000 \mathrm{~g}, 40 \mathrm{~min}, 4^{\circ} \mathrm{C}\right)$ was resuspended in the disruption buffer and dialysed overnight against buffer $\mathrm{A}$ (10 $\mathrm{mM}$ Tris/ $\mathrm{HCl}, \mathrm{pH} 8 \cdot 0,1 \mathrm{mM}$ DTT). The desalted enzyme solution was applied to a DEAE-Sepharose-CL-6B column $(3 \times 9 \mathrm{~cm})$ equilibrated with buffer $A$. After washing with buffer $A$, bound enzyme was eluted with a linear concentration gradient of $0.05-0.4 \mathrm{M} \mathrm{KCl}$ in buffer $\mathrm{A}$. Protein was read as $A_{\mathbf{2 8 0}}$ 
and the concentration gradient checked using a conductance meter. Fractions selected for enzyme studies were desalted and concentrated using Amicon concentrating cones.

Isolated peroxisomes or mitochondria were sonicated in buffer A containing $0 \cdot 1 \%$ Triton X-100 for $3 \mathrm{~min}$ and ultracentrifuged at $139000 \mathrm{~g}, 1 \mathrm{~h}, 4{ }^{\circ} \mathrm{C}$. Supernatants were applied to DEAESepharose-CL-6B columns $(1.5 \times 5 \mathrm{~cm})$. CAT was eluted with a linear concentration gradient in buffer $\mathrm{A}$ of $0.05-0.4 \mathrm{M} \mathrm{KCl}$.

All procedures were carried out at $04^{\circ} \mathrm{C}$.

Enzyme assays. CAT was assayed according to the coupled method of Chase (1969). The reaction mixture consisted of $50 \mathrm{mM}$ Tris/ $\mathrm{HCl}, \mathrm{pH} 7.8,5 \mathrm{mM}$ acetylcarnitine, $3.25 \mathrm{mM}$ CoASH, $5 \mathrm{mM}$ EDTA, $50 \mathrm{mM}$ L-malate $(\mathrm{pH} 8.0), 0.5 \mathrm{mM}$ NAD $^{+}(\mathrm{pH} \mathrm{6.0)}, 5$ units citrate synthase, 4 units malate dehydrogenase and $2 \mathrm{mM} \mathrm{KCN}$. The reaction was started with the addition of acetylcarnitine in the presence of enzyme extract. The reduction of $\mathrm{NAD}^{+}$was followed at $340 \mathrm{~nm}$ $\left(\varepsilon_{340}=6.22 \times 10^{6} \mathrm{~cm}^{-1} \mathrm{M}^{-1}\right)$

Substrate specificity and apparent kinetic constants were determined using the method of Kohlhaw \& Tan-Wilson (1977) at $30^{\circ} \mathrm{C}$, following the formation of free $\mathrm{CoA}$ via $5,5^{\prime}$-dithiobis(2-nitrobenzoic acid) (DTNB) at $412 \mathrm{~nm} \quad\left(\varepsilon_{412}=\right.$ $\left.13.6 \times 10^{6} \mathrm{~cm}^{-1} \mathrm{M}^{-1}\right)$. The reaction mixture contained $50 \mathrm{mM}$ Tris $/ \mathrm{HCl}, \mathrm{pH} 8.0,0.4 \mathrm{mM}$ DTNB, $1.25 \mathrm{mM}$ L-carnitine and acyl-CoA $(6 \cdot 25-200 \mu \mathrm{M})$.

2-Oxoglutarate dehydrogenase was measured at $30^{\circ} \mathrm{C}$ by the method of Osmani \& Scrutton (1983). The reaction mixture consisted of $100 \mathrm{mM} \mathrm{K} \mathrm{K}^{+}$-HEPES, $\mathrm{pH} 8.0,8.4 \mathrm{mM} \mathrm{2-}$ oxoglutarate, $2.5 \mathrm{mM}$ DTT, $1 \mathrm{mM}$ thiamin diphosphate, $0.5 \mathrm{mM} \mathrm{NAD}^{+}$and $0.1 \mathrm{mM} \mathrm{CoASH}$. The reaction was initiated by the addition of enzyme extract and followed by measuring the reduction of $\mathrm{NAD}^{+}$at $340 \mathrm{~nm}$.

Catalase was measured by the method of Haywood \& Large (1981): $0.1 \mathrm{ml}$ extract was added to $2.9 \mathrm{ml}$ reagent consisting of $0.1 \mathrm{ml} 30 \%(\mathrm{v} / \mathrm{v}) \mathrm{H}_{2} \mathrm{O}_{2}$ in $50 \mathrm{ml} 50 \mathrm{mM}$ phosphate buffer, $\mathrm{pH} 7 \cdot 0$. The time taken for the $A_{240}$ to fall from 0.45 to 0.4 was determined at $25{ }^{\circ} \mathrm{C}$. This corresponded to decomposition of $3.45 \mu \mathrm{mol} \mathrm{H}_{2} \mathrm{O}_{2}$ in $3 \mathrm{ml}$. Activity was expressed in Sigma units: $3 \cdot 45 /$ time ( $\mathrm{min}$ ) required].

Cytochrome $c$ oxidase was measured by the method of Minnaert (1961). Oxidation of reduced cytochrome $c$ was followed at $550 \mathrm{~nm}$. The reaction mixture contained $65 \mathrm{mM}$ phosphate buffer, $\mathrm{pH} 7 \cdot 4,1 \mathrm{mM}$ EDTA, 0.006-0.07 mM cytochrome (reduced with ascorbic acid and dialysed overnight against $50 \mathrm{mM}$ phosphate buffer prior to use). Change in absorbance $\left(\varepsilon_{550}=22.4 \times 10^{6} \mathrm{~cm}^{-1} \mathrm{M}^{-1}\right)$ was monitored at $25^{\circ} \mathrm{C}$ on addition of the extract.

Protein estimations were made by the method of Bradford (1976).

\section{RESULTS AND DISCUSSION}

\section{Internal cell structures}

The basal growth medium used in this study was designed such that at $30^{\circ} \mathrm{C}$ with adequate aeration, $C$. albicans $\mathrm{C} 316$ grew in the yeast form irrespective of the carbon source supplied (see Fig. 1a, b, c). Despite the maintenance of a regular yeast form on the different media there were some striking differences in the internal cell structure. Under the fixation protocol $\left(\mathrm{KMnO}_{4}\right)$ used here, the cytoplasm
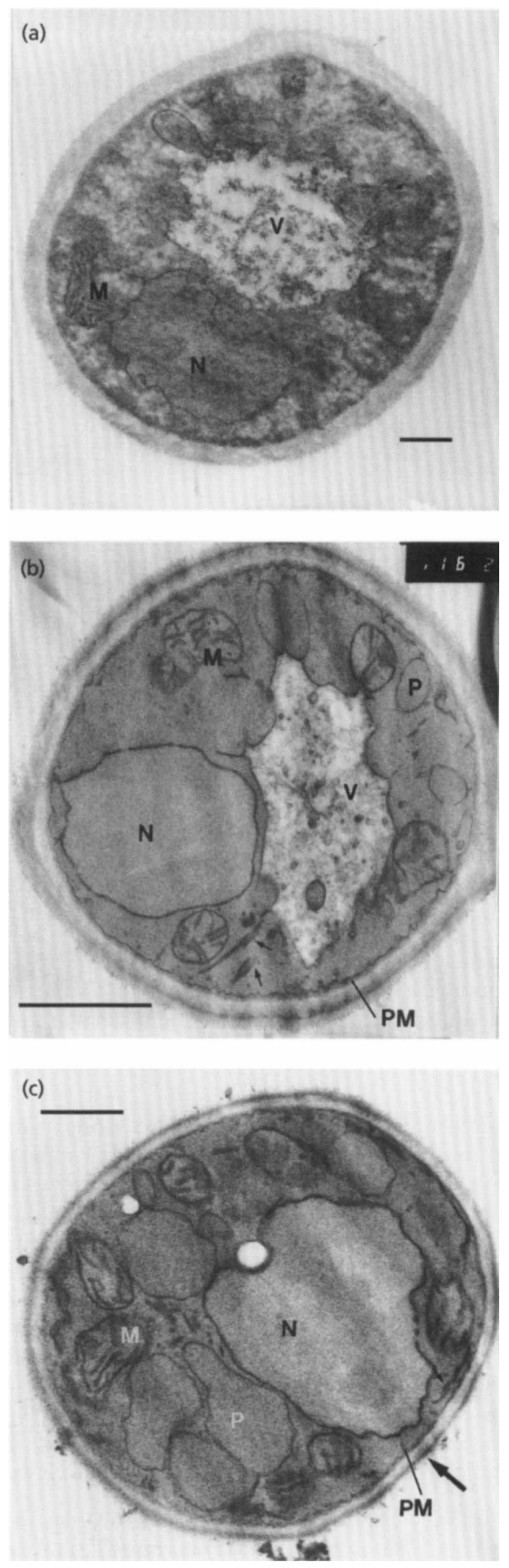

Fig. 1. Transmission electron microscopy of C. albicans C316 grown at $30^{\circ} \mathrm{C}$ in medium supplemented with (a) glucose, (b) triolein or (c) serum. $M$, mitochondrion; $N$, nucleus; $V$, vacuole; $P$, peroxisome; PM, plasma membrane; small arrows, distended endoplasmic reticulum; large arrow, trans-cell wall structure. Bars, $1 \mu \mathrm{m}$ for (a) and (b); $0.5 \mu \mathrm{m}$ for (c). 


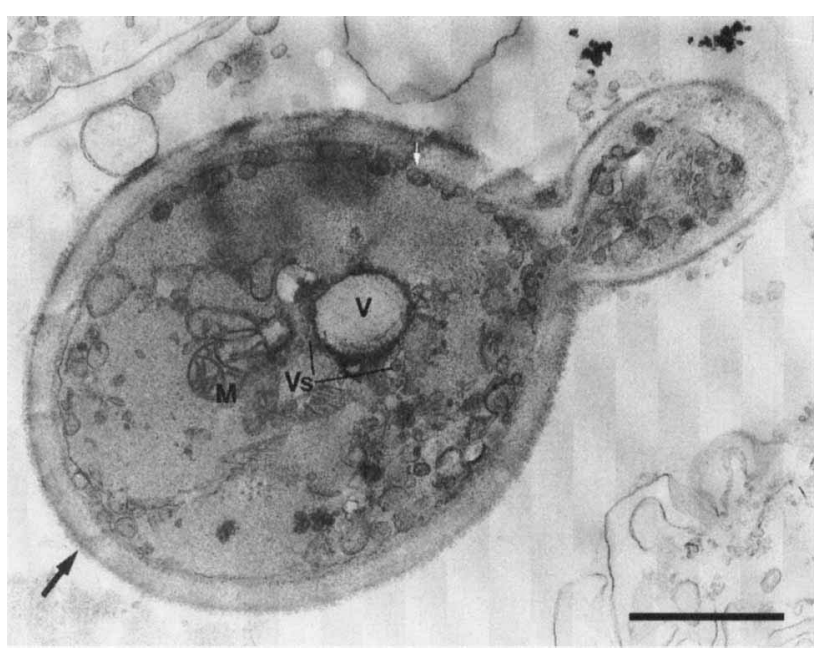

Fig. 2. Transmission electron microscopy of $C$. albicans C316 washed from the IP cavity of female $\mathrm{CR}-\mathrm{H}$ mice, $6 \mathrm{~h}$ postinfection. $M$, mitochondrion; $V$, vacuole; Vs, vesicles; small arrow, double-membraned vesicle; large arrow, trans-cell-wall structure. Bar, $1 \mu \mathrm{m}$.

of the cells grown on glucose (Fig. 1a) had a very flocculent appearance, unlike the cells grown on triolein or serum (Figs $1 \mathrm{~b}$ and $1 \mathrm{c}$, respectively.) The flocculent appearance of the cells grown on glucose made it difficult to discern the plasma membrane, which is only partially visible in the lower portion of Fig. 1(a).

The plasma membrane of the triolein-grown (Fig. 1b) and serum-grown (Fig. 1c) cells appeared to be particularly crenulated. Such invaginations of the plasmalemma are a common feature of Candida species and yeasts in general (Fisher et al., 1982).

A proliferation of microbodies or peroxisomes could be seen in both the triolein-grown (Fig. 1b) and serumgrown cells (Fig. 1c). In both cases, intracytoplasmic membranes, tentatively identified as the endoplasmic reticulum, were visible (Fig. 1b, c). In the cell in Fig. 1(b), some of the endoplasmic reticulum seemed especially distended at one end (arrows). Much of the membranous material appeared to be associated with the periphery of the cell. The intimate association of such membranes with the periphery of the cell has previously been observed in C. albicans by Rajasingham \& Challacombe (1988). This can be seen in the triolein-grown cells (see Fig. 7a) and most clearly in the serum-grown cells (Figs 1c, 7b).

IP conditions appeared to be favourable for growth of the yeast in vivo, as could be seen by the budding of the cells (Fig. 2). At $6 \mathrm{~h}$ post-infection, there was a proliferation of microbodies within the cell (Fig. 2), some of which appeared to lie between the plasma membrane and the cell wall (also noted by Fischer et al., 1982). There was a considerable accumulation of vesicles around the vacuole. Vesicular inclusions were clearly present and some vesicles appeared to have a double membrane (small arrow). Double-membraned vesicles were also evident in the electron micrographs of $C$. albicans presented by Anderson et al. (1990).

Due to clearance of the Candida cells from the IP cavity, in vivo conditions cannot be maintained for long periods within the peritoneum. However, by using an intravenous injection of a sub-lethal dose of $C$. albicans C316, a period of infection of over $24 \mathrm{~h}$ was maintained. Under such conditions, there were extreme changes in the subcellular organization of the cell compared to in vitro-cultured cells. As in the IP cells, there was an accumulation of vesicles (Fig. 3a, b). Some vesicles and large vacuolar organelles appeared to contain inclusions (arrows). The large vacuoles also contained other vesicles. Endoplasmic reticulum was again evident at the periphery of the hyphal tip (Fig. 3b). There was no evidence of the classic eukaryotic mitochondrion, although some of the large vacuolar structures had double membranes. These structures may be exaggerated examples of mitochondria with large matrix volumes. Tanaka et al. (1985) and Aoki et al. (1989) established that the mitochondria migrated to the tip of the growing hyphae, so one would expect to be able to see evidence of a mitochondrion in Fig. 3(b), but none was evident.

Vesicles were seen to accumulate around the vacuolar membrane in the cells grown in vivo (Figs 2 and 3). As $C$. albicans can secrete various hydrolytic enzymes (see Ross $e t$ al. 1990), such vesicles may be pinched off from the central vacuole and migrate to the periphery of the cell where the enzymes could be secreted.

In addition to the vacuolar vesicles, a proliferation of peroxisomes was evident in cells grown on triolein or serum or when held in vivo (Figs 1b, c, 2, 3a, b). Peroxisomes were identified according to the descriptions of Vamecq \& Draye (1989). Peroxisomes are generally considered to be the site of $\beta$-oxidation in yeasts and fungi (Veenhuis \& Harder, 1991; Ratledge, 1994). They are also the sites where amino acids, uric acid and purines are metabolized (Veenhuis \& Harder, 1987; Mannaerts \& Van Veldhoven, 1990).

Although the presence of peroxisomes was clearly evident in the in vivo-grown cells, it was not possible to recover sufficient numbers of $C$. albicans to carry out any enzymological investigation.

\section{Peroxisomes, acetate metabolism and CAT activities}

$\beta$-Oxidation of fatty acids and deamination and degradation of amino acids to acetyl-CoA increases the requirement for translocation of acetyl units between cellular compartments (see Fig. 6). In C. albicans grown on glucose, CAT is the main route through which acetyl$\mathrm{CoA}$ is exchanged between mitochondria and the cytosol (Sheridan et al., 1990). Ueda et al. (1982) found that in C. tropicalis, grown on alkanes, CAT had a dual location, being both peroxisomal and mitochondrial. This dual location has now been verified for $C$. albicans using DEAE chromatography. Fig. 4 shows a typical elution profile of 


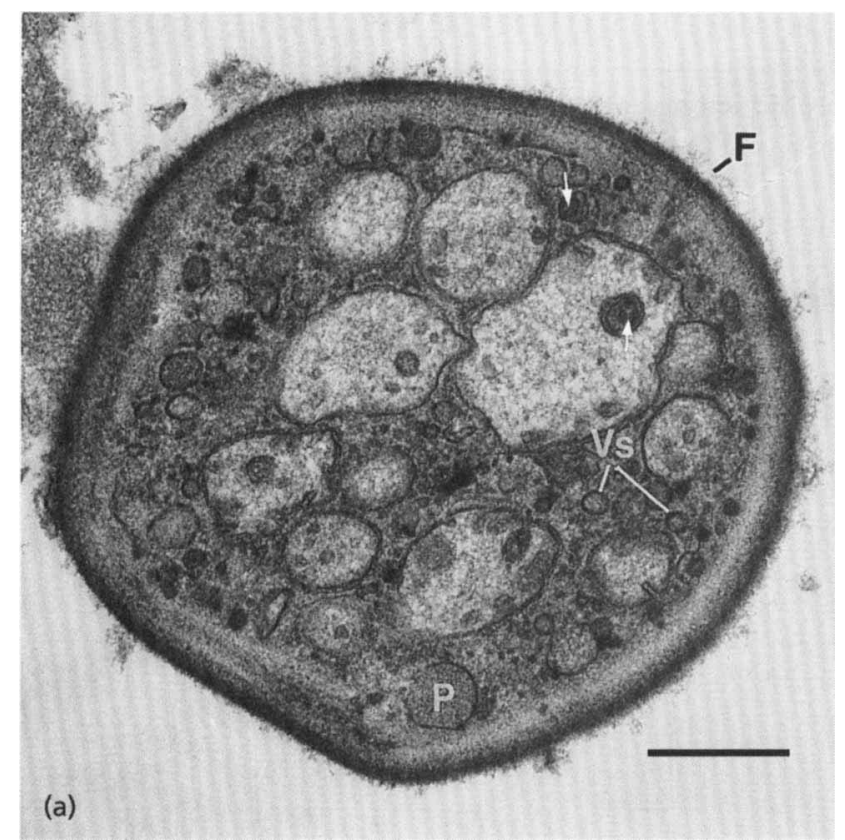

Fig. 3. Transmission electron microscopy of C. albicans C316 material; HT, hyphal tip; Bars, $0.5 \mu \mathrm{m}$ for (a), $1 \mu \mathrm{m}$ for (b). obtained from the kidneys of female CR-H mice $24 \mathrm{~h}$ postinfection. $V$, vacuole; $V s$, vesicles; $P$, peroxisome; $F$, fibrillar
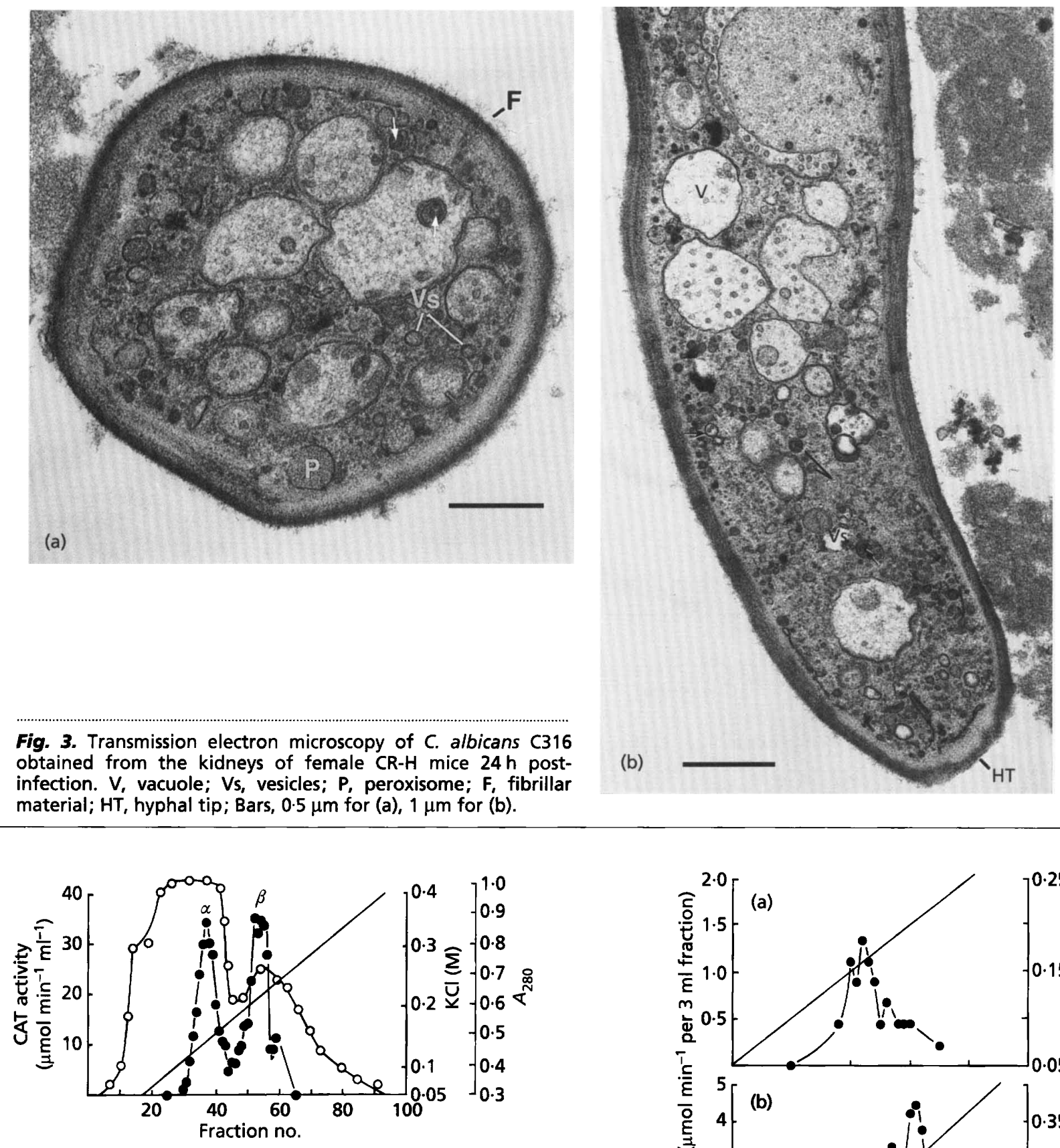

Fig. 4. Elution profile from DEAE-Sepharose-CL-6B of CAT $-\alpha$ and $\beta$ forms - obtained from C. albicans C316 grown on triolein $(2.5 \mathrm{mM})$ at $30^{\circ} \mathrm{C}$. Total CAT activity in each $1 \mathrm{ml}$ fraction; $\mathrm{O}$, protein as $A_{280} ;-, \mathrm{KCl}$ gradient as eluant.

CAT obtained from $C$. albicans grown on triolein. Two main peaks of CAT activity were eluted, $\alpha$ at $0 \cdot 14 \mathrm{M} \mathrm{KCl}$ and $\beta$ at $0.22 \mathrm{M} \mathrm{KCl}$, with a small peak of activity at $0.24 \mathrm{M} \mathrm{KCl}$. When extracts of isolated mitochondria and peroxisomes were separately applied to DEAE columns, a CAT profile corresponding to $\alpha$ in Fig. 4 was obtained from the peroxisomes (Fig. 5a) and to $\beta$ from the mitochondria (Fig. 5b). Each main peak appeared to consist of two peaks, which may represent aggregated forms of CAT (Kozulic et al., 1987). Elution profiles of

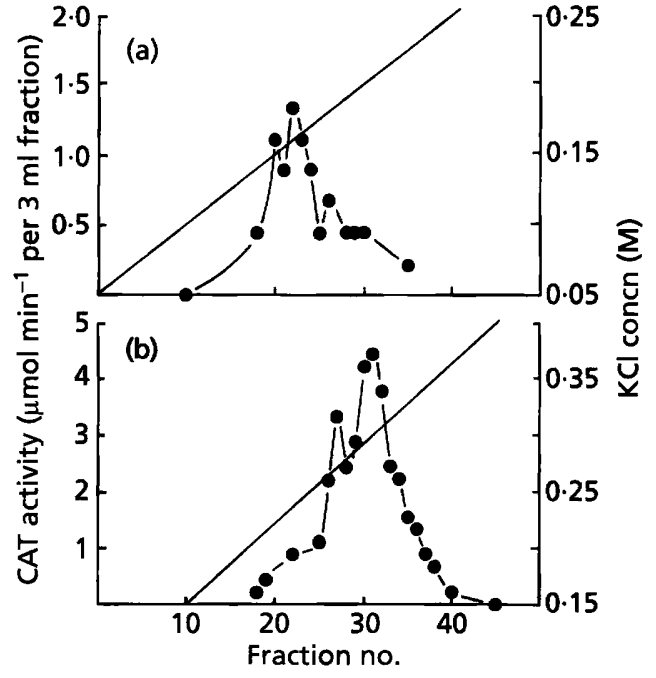

Fig. 5. Elution profiles of CATs (O) obtained from isolated subcellular organelles of $C$. albicans C316 grown on triolein $\left(2.5 \mathrm{mM}\right.$ ) at $30^{\circ} \mathrm{C}$. (a) CAT ( $\alpha$ form) obtained from peroxisomes; (b) CAT ( $\beta$ form) obtained from mitochondria. Total activities given per $3 \mathrm{ml}$ fraction. _-, $\mathrm{KCl}$ gradient as eluant.

CAT, consistent within the values for CAT in Table 1, were found for $C$. albicans grown on glucose, triolein or serum (not shown). 
Table 1. Carbon-source-dependent changes in subcellular CAT activity

\begin{tabular}{|c|c|c|c|}
\hline \multirow[t]{2}{*}{ Carbon source } & \multirow[t]{2}{*}{ Enzyme* } & \multicolumn{2}{|c|}{$\begin{array}{c}\text { Specific activity } \\
{\left[\mu \mathrm{mol} \mathrm{min}^{-1}(\mathrm{mg} \text { protein })^{-1}\right] \dagger}\end{array}$} \\
\hline & & Mitochondria & Peroxisomes \\
\hline \multirow[t]{3}{*}{ Glucose $(56 \mathrm{mM})(n=2)$} & CAT & $0.06 \pm 0.0066$ & $0.002 \pm 0.0004$ \\
\hline & $2 \mathrm{ODDH}$ & $0.02 \pm 0.0018$ & ND \\
\hline & $\operatorname{ccox}$ & $0.002 \pm 0.00018$ & 0 \\
\hline \multirow[t]{3}{*}{ Triolein $(2.5 \mathrm{mM})(n=4)$} & CAT & $4.5 \pm 0.29$ & $8 \cdot 8 \pm 0 \cdot 32$ \\
\hline & $\mathrm{CCO} x$ & $4 \cdot 9 \pm 0 \cdot 22$ & $0.03 \pm 0.0012$ \\
\hline & Catalase & $740 \pm 25 \cdot 9$ & $3050 \pm 244$ \\
\hline \multirow[t]{3}{*}{$\operatorname{Serum}(10 \%, \mathrm{v} / \mathrm{v})(n=2)$} & CAT & $0 \cdot 27 \pm 0.032$ & $0.04 \pm 0.0056$ \\
\hline & $\operatorname{cCOx}$ & ND & ND \\
\hline & Catalase & ND & ND \\
\hline
\end{tabular}

*CAT, carnitine acetyltransferase; $2 \mathrm{ODH}, 2$-oxoglutarate dehydrogenase; $\mathrm{CCOx}$, cytochrome $c$ oxidase.

† Enzyme activities are expressed as the mean \pm range for $n=2, \pm \operatorname{sEM}$ for $n=4$. ND, Not determined.

Table 2. Substrate specificity of CAT, derived from different sources, for acyl-CoA derivatives

\begin{tabular}{|c|c|c|c|c|c|}
\hline \multirow[t]{3}{*}{ Acyl-CoA derivative } & \multicolumn{5}{|c|}{ Substrate specificity $(\%) *$} \\
\hline & \multicolumn{2}{|c|}{ C. albicans $\dagger$} & \multicolumn{2}{|c|}{ C. tropicalis $\ddagger$} & \multirow{2}{*}{$\begin{array}{c}\text { Human } \\
\text { liver } \$\end{array}$} \\
\hline & Peroxisomal & Mitochondrial & Peroxisomal & Mitochondrial & \\
\hline Acetyl-CoA & $100 \pm 2 \cdot 02(51 \cdot 6)$ & $100 \pm 1 \cdot 56(21 \cdot 8)$ & $100(88 \cdot 5)$ & $100(113)$ & 60 \\
\hline Propionyl-CoA & $9 \cdot 2 \pm 3 \cdot 52$ & $25 \cdot 7 \pm 4 \cdot 62$ & $9 \cdot 4$ & 15 & $100(131)$ \\
\hline Butyryl-CoA & $1 \cdot 3 \pm 3 \cdot 7$ & $1 \cdot 2 \pm 4 \cdot 21$ & $0 \cdot 1$ & $0 \cdot 3$ & 70 \\
\hline Octanoyl-CoA & 0 & 0 & 0 & 0 & 30 \\
\hline Palmitoyl-CoA & 0 & 0 & 0 & 0 & 0 \\
\hline
\end{tabular}

* The results are shown as percentages of the maximum value [means $\pm \operatorname{sEM}(n=3)]$, with absolute $100 \%$ values [units (mg protein) ${ }^{-1}$ ] given in parentheses.

† Results from this study, using partially purified enzymes, assayed at $30^{\circ} \mathrm{C}$.

$\ddagger$ Results from Ueda et al. (1982) using purified enzymes, assayed at $30^{\circ} \mathrm{C}$.

\Results from Bloisi et al. (1990) using purified enzyme, assayed at $37^{\circ} \mathrm{C}$.

The properties of the mitochondrial and peroxisomal CAT of C. albicans $\mathrm{C} 316$ grown on triolein were similar to those of $C$. tropicalis (Ueda et al., 1982). As with $C$. tropicalis, the peroxisomal enzyme had a $\mathrm{pH}$ optimum of $7 \cdot 5-7 \cdot 8$. However, the mitochondrial enzyme had a $\mathrm{pH}$ optimum of $8 \cdot 0$. Both enzymes were specific for acetylCoA, although both showed some activity with propionyl-CoA (Table 2). No activity was found with medium- or long-chain acyl-CoAs.

The apparent Michaelis constants of mitochondrial and peroxisomal CAT for acetyl-CoA or propionyl-CoA were determined from Lineweaver-Burk plots. Peroxisomal CAT showed a greater affinity for both substrates compared to mitochondrial CAT (Table 3). The mitochondrial CAT showed affinities for both substrates in keeping with those found for $C$. tropicalis (Ueda et al.,
1982). The peroxisomal CAT, however, showed affinities for both substrates similar to those of human liver CAT (Bloisi et al., 1990), being approximately three times the affinities of peroxisomal CAT from $C$. tropicalis.

As in C. tropicalis, peroxisomes and associated CAT activity are inducible in $C$. albicans and depend upon which carbon source is used for growth. The internal morphological changes in $C$. albicans in response to glucose, triolein or serum can be explained in terms of carbon catabolism and acetyl-CoA translocation towards energy and building blocks (Fig. 6). When the yeast is utilizing glucose or other carbohydrates, the mitochondria predominate (Fig. 6a). There is no peroxisomal proliferation (Fig. 1a) or induction of peroxisomal CAT (Table 1). Glycolysis supplies pyruvate, which enters the mitochondrion and is then converted by pyruvate de- 
Table 3. Apparent Michaelis constants of CAT from various sources for acyl-CoA derivatives.

\begin{tabular}{|lcc|}
\hline CAT source & \multicolumn{2}{c|}{$K_{\mathrm{m}}$ value $(\mu \mathrm{M})$} \\
\cline { 2 - 3 } & Acetyl-CoA & $\begin{array}{c}\text { Propionyl- } \\
\text { CoA }\end{array}$ \\
\hline C. albicans C316* & & \\
Mitochondrial & $38( \pm 5)$ & $185( \pm 17 \cdot 9)$ \\
Peroxisomal & $14( \pm 2 \cdot 4)$ & $34( \pm 7 \cdot 3)$ \\
C. tropicalis pk233 $\dagger$ & 36 & 162 \\
Mitochondrial & 42 & 100 \\
Peroxisomal & 21 & 28 \\
Human liver $(40000 \mathrm{~g}$ & & \\
supernatant) $\ddagger$ & & \\
\hline
\end{tabular}

* Results from this study, using partially purified enzymes, assayed at $30^{\circ} \mathrm{C}$ [means \pm range $(n=2)$ ].

$\dagger$ Results from Ueda et al. (1982) using purified enzymes, assayed at $30^{\circ} \mathrm{C}$.

$\ddagger$ Results from Bloisi et al. (1990) using purified enzyme, assayed at $37^{\circ} \mathrm{C}$.

hydrogenase into acetyl-CoA. For reactions other than the tricarboxylic acid (TCA) cycle, e.g. lipid biosynthesis, acetyl-CoA must be translocated out of the mitochondrion into the cytosol. In $C$. albicans, this is via acetylcarnitine and CAT (Sheridan et al., 1990) as acetyl-CoA itself is too bulky to cross the mitochondrial membrane.

When $C$. albicans was grown on triolein, there was a proliferation of peroxisomes (Fig. 1b) and an induction of peroxisomal CAT activity to twice that found in the mitochondria (Table 1). Acetyl-CoA produced by $\beta$ oxidation of acyl-CoA within the peroxisome again cannot cross the membranes because of its size and, as with the mitochondrion, is translocated as its carnitine derivative, via the action of CAT (Fig. 6b). A portion of the acetylcarnitine will go towards sterol synthesis and other reactions (but not fatty acid biosynthesis, which is repressed under these conditions) in the cytosol and the remaining acetylcarnitine will then enter the mitochondrion, where it is converted back into acetyl-CoA by mitochondrial CAT and is then fed into the TCA cycle and also contributes to gluconeogenesis by its conversion to oxaloacetate.

Though mitochondrial CAT and peroxisomal CAT activities were 4-fold and 20 -fold greater, respectively, when serum was used as carbon source rather than glucose (Table 1), the peroxisomal activity $\left[0.04 \mu \mathrm{mol} \mathrm{min} \mathrm{m}^{-1}\right.$ (mg protein) $\left.{ }^{-1}\right]$ appeared low for the large peroxisomes observed in the cell (Fig. 1c). It is possible that the enzymes of the glyoxylate bypass pathway of the TCA cycle (acetyl-CoA $\rightarrow$ citrate $\rightarrow$ isocitrate $\rightarrow$ glyoxylate $\rightarrow$ malate) may play a role in $C$. albicans. Glyoxylate bypass enzymes have been located in the peroxisomes of $C$. tropicalis (Okada et al., 1986) and $C$. utilis (Zwart et al., 1983). Thus, peroxisomal amino acid degradation or acyl CoA $\beta$-oxidation (Fig. 6b) would supply acetyl units to the cytosol and mitochondrion via the action of CAT (peroxisomal and mitochondrial). Acetyl-CoA would also enter the glyoxylate bypass reactions of the peroxisome and lead to the formation of $\mathrm{C}_{4}$ compounds (mainly malate and oxaloacetate), which could then be transferred either into the cytosol as the starting materials for gluconeogenesis or into the mitochondrion for the provision of energy via the reactions of the TCA cycle.

C. albicans C316 appears capable of responding to a complex nutritional environment. In vivo, the peroxisomal structures (Fig. 2) demonstrate the ability of this organism to degrade carbon sources such as lipids and protein which could be expected to be 'natural' substrates for an organism growing within animal tissues.
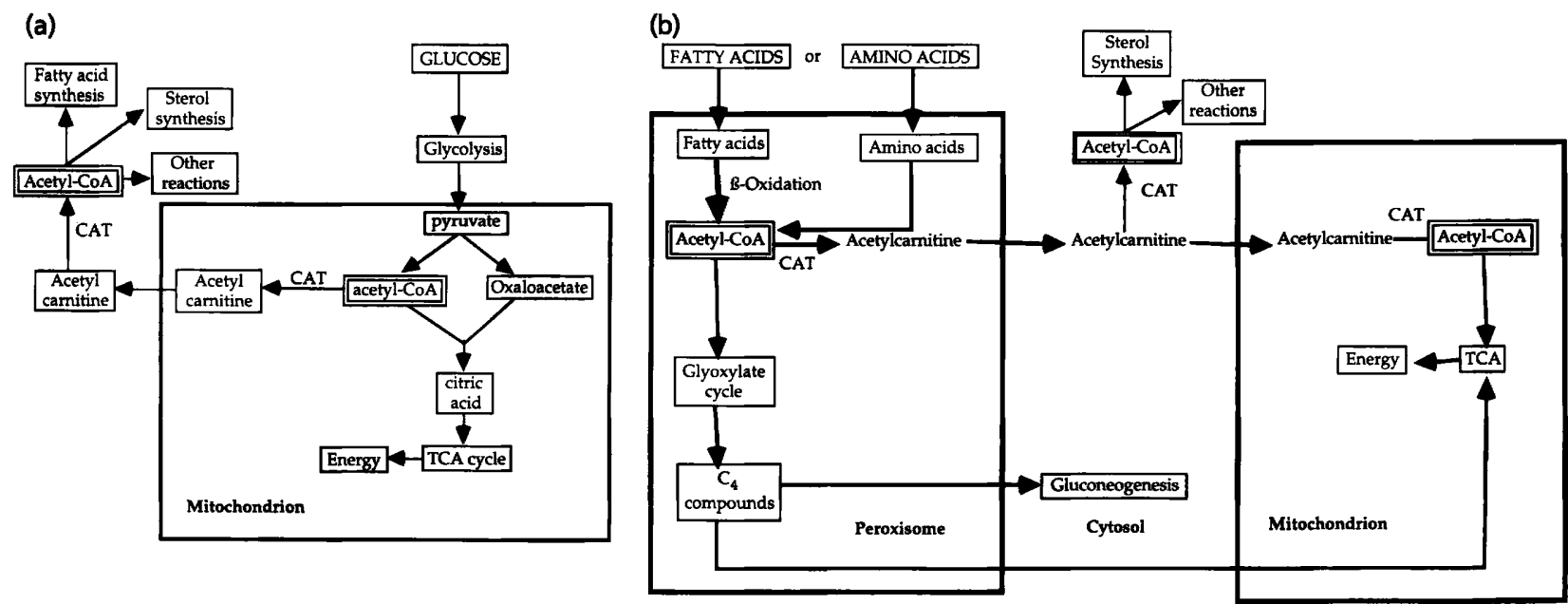

Fig. 6. Diagrammatic representations of the role of carnitine acetyltransferases (CAT) in C. albicans growing (a) on glucose and (b) on triolein (or host lipids) or on amino acids derived from serum. TCA, tricarboxylic acid cycle. 


\section{Cell wall structures}

In addition to the marked alterations in the membranous subcellular organelles as a response to growth medium, structural changes in the cell wall were also evident.

Cells grown on triolein (Figs 1b, 7a) or serum (Figs 1c, 7b) and cells grown in vivo (Figs 2, 3a), especially those from the $6 \mathrm{~h}$ IP washings (Fig. 2), had an increased amount of the outer electron-dense fibrillar layer. This layer was not always so obvious in cells obtained from kidney tissue (Fig. 3b). (It is possible that during the recovery of these latter cells, much of the outer layer had been washed off.) The synthesis of this outer fibrillar layer has previously been associated with the nutritional status : an intercellular matrix was seen by scanning electron microscopy on the surface of $C$. albicans when grown as colonies on agar (Joshi et al., 1975) and growth of C. albicans on various carbohydrates, particularly galactose, in liquid media induced the synthesis of extracellular polymeric material (McCourtie \& Douglas, 1981; 1985).

In addition to the outer fibrillar layer of $C$. albicans C316, an electron-dense material penetrating the cell wall to the plasmalemma side was seen, with a mass of fibrillar material protruding from the exterior of the cell. These cell wall structures were seen in cells grown on either triolein or serum and in vivo but not in those grown on glucose (Fig. 1a). At high magnification (Fig. 7a, b), the trans-wall structures were clearly seen to consist of a cluster of distinct lines of electron-dense material penetrating the wall, each remaining a distinct entity. At the cell surface, the structures continued and protruded out of the cell wall to the exterior of the cell. The endoplasmic reticulum located at the periphery of the cell was in close proximity with these cell wall structures (Fig. 7a, b). This relationship between the endoplasmic reticulum and cell wall structures was noted by Osumi et al. (1975) in $C$. tropicalis pK233 grown on n-alkanes and in $C$. albicans (Tokunaga et al., 1987).

The function of these trans-wall structures is not clear, although Poulain et al. (1989) demonstrated that they were due to the secretion of glycoproteins. The close association of endoplasmic reticulum with these structures would suggest protein production and possible pore formation. Anderson et al. (1990) suggested a secretory role for these trans-wall structures, with vesicles arising from the vacuole migrating through the cytosol and the pore structures to the exterior of the cell (doublemembraned vesicles could be seen at the exterior of the cell). Thus, the trans-wall structures may be a route for the increased production of fibrillar material for the exterior of the cell. This material has been associated with an increased capacity of the yeast to adhere to host cell surfaces and synthetic surfaces (reviewed by Douglas, 1987). The production of an extracellular fibrillar layer (mannoprotein) by $C$. albicans is thought to be strain specific and to be more common in virulent strains than in avirulent ones (Houston \& Douglas, 1989). Related fibrillar structures have been seen in Candida spp. grown on alkanes (Osumi et al., 1975) and may be important for uptake of a hydrophobic substrate across a hydrophilic
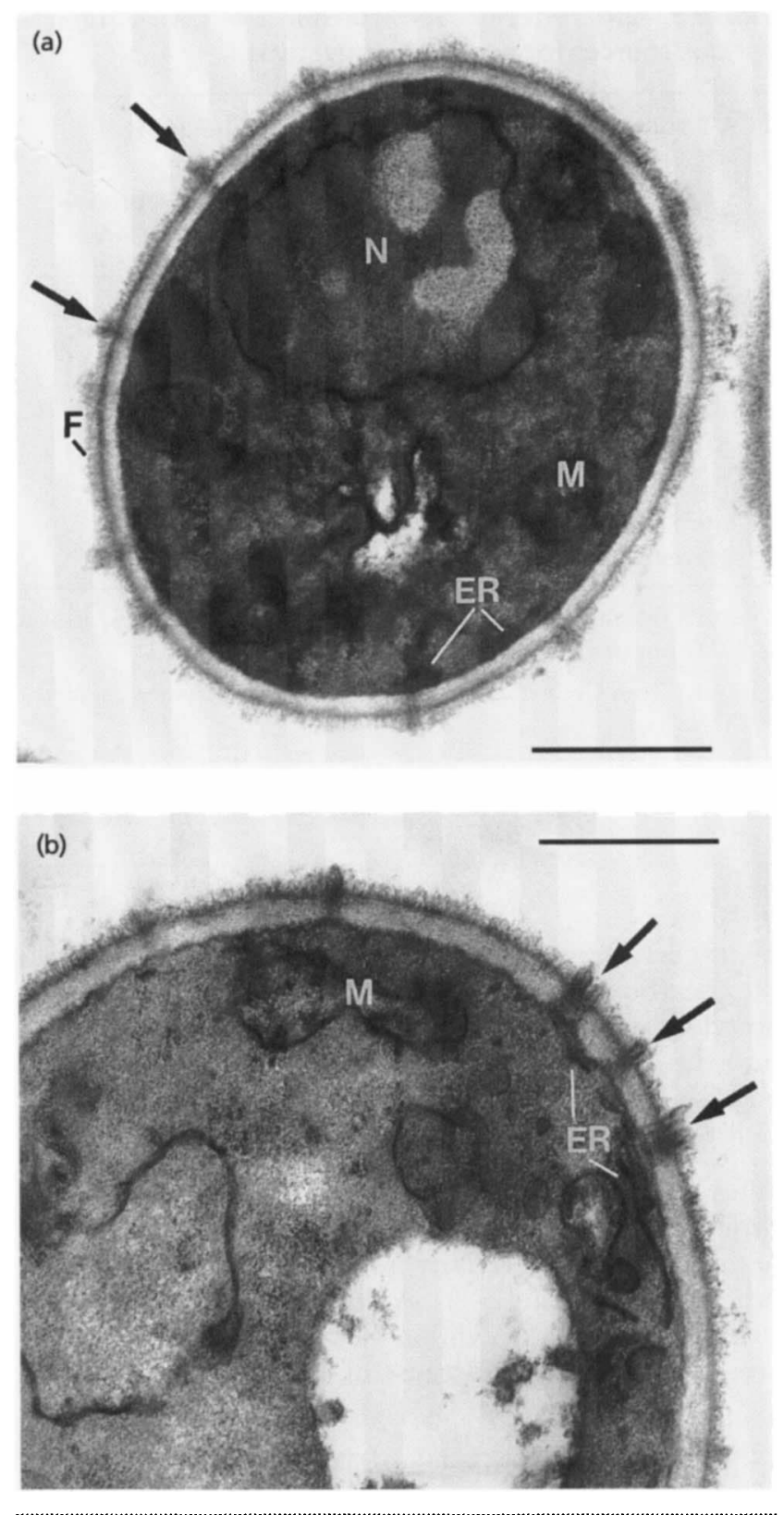

Fig. 7. Transmission electron microscopy of the trans-cell-wall structures of $\mathrm{C}$. albicans $\mathrm{C} 316$ induced by growth at $30^{\circ} \mathrm{C}$ in medium supplemented with serum (a) or triolein (b). $N$, nucleus; $M$, mitochondrion; ER, endoplasmic reticulum; $F$, fibrillar material; large arrow, trans-cell-wall structures. Bars, $1 \mu \mathrm{m}$.

cell wall (see Hommel \& Ratledge, 1993). It is possible the structures observed here with $C$. albicans fulfil a similar function for the uptake of fatty acids derived either from triolein or from the host lipids.

Finally, yeast mitochondria have been found to exert control over the cell-surface complex, influencing agglutination, tolerance to drugs, utilization of sugars and plasma membrane proteins (Prasad, 1985, and references therein). Under $\mathrm{O}_{2}$ limitation, or in the presence of excess reducing equivalents due to oxidative biochemical pro- 
cesses, one would expect respiratory changes and, thus, possible alterations in the mitochondria. These changes may be manifest through cell wall changes in $C$. albicans C316.

\section{ACKNOWLEDGEMENTS}

We are grateful to Dr Peter A. Chalk of Glaxo-Wellcome Research Ltd for his interest in this work, which was supported by SERC-CASE research studentship to R. S. in collaboration with Glaxo Group Research. We are indebted to Oonagh Kingsman (Glaxo-Wellcome) for undertaking the experiments involving animals.

\section{REFERENCES}

Anderson, J., Mihalik, R. \& Soll, D. R. (1990). Ultrastructure and antigenicity of the unique cell-wall pimple of the Candida opaque phenotype. J Bacteriol 172, 224-235.

Aoki, S., Itokuwa, S., Nakamura, Y. \& Masuhara, T. (1989). Mitochondrial behavior during the yeast-hypha transition of Candida albicans. Microbios 60, 79-86.

Bloisi, W., Colombo, I., Garavaglia, B., Giardini, R., Finocchiaro, G. \& Didonato, S. (1990). Purification and properties of carnitine acetyltransferase from human liver. Eur $J$ Biochem 189, 539-546.

Bradford, M. M. (1976). A rapid and sensitive method for the quantitation of microgram quantities of protein utilizing the principle of protein-dye binding. Anal Biochem 72, 248-254.

Chase, J. F. A. (1969). Carnitine acetyltransferase. Methods Enzymol 13, 387-393

Crabtree, B., Gordon, M. J. \& Christie, S. L. (1990). Measurement of the rates of acetyl-CoA hydrolysis and synthesis from acetate in rat hepatocytes and the role of these fluxes in substrate cycling. Biochem J 270, 219-225.

Delaissé, J. M., Martin, P., Verheyenbouvy, M. F. \& Nyns, E. J. (1981). Subcellular distribution of enzymes in the yeast Saccbaromyces lipolytica, grown on normal hexadecane, with special reference to the omega-hydroxylase. Biochim Biopbys Acta 676, 77-90.

Douglas, L. J. (1987). Adhesion of Candida species to epithelial surfaces. CRC Crit Rev Microbiol 15, 27-43.

Fischer, W., Bruckner, B. \& Meyer, H. W. (1982). Ultrastructural alterations at the cell-wall and plasma-membrane of Candida Spec $\mathrm{H}$ induced by normal-alkane assimilation. Z Allg Mikrobiol 22, 227-236.

Gow, N. A. R. \& Gooday, G. W. (1984). A model for the germ tube formation and mycelial growth form of Candida albicans. Sabouraudia 22, 137-143.

Haywood, G. W. \& Large, P. J. (1981). Microbial oxidation of amines - distribution, purification and properties of two primary amine oxidases from the yeast Candida boidinii grown on amines as sole nitrogen-source. Biochem J 199, 187-201.

Hirai, M., Shimizu, S., Teranishi, Y., Tanaka, A. \& Fukui, S. (1972). Studies on the physiology-metabolism of hydrocarbon-utilizing microorganisms. Effects of hydrocarbon on the morphology of Candida tropicalis pK233. Agric Biol Chem 36, 2335-2343.

Hitchcock, C. A., Barrett Bee, K. J. \& Russell, N. J. (1989). The lipid-composition and permeability to the triazole antifungal antibiotic ICI-153066 of serum-grown mycelial cultures of Candida albicans. J Gen Microbiol 135, 1949-1955.

Holdsworth, J. E., Veenhuis, M. \& Ratledge, C. (1988). Enzyme activities in oleaginous yeasts accumulating and utilizing exogenous or endogenous lipids. J Gen Microbiol 134, 2907-2915.
Hommel, R. \& Ratledge, C. (1993). Biosynthetic mechanisms of low molecular weight surfactants and their precursor molecules. In Biosurfactants: Production, Properties, Applications, pp. 3-63. Edited by N. Kosaric. New York: Marcel Dekker.

Houston, J. G. \& Douglas, L. J. (1989). Interaction of Candida albicans with neutrophils - effect of phenotypic changes in yeast cell-surface composition. J Gen Microbiol 135, 1885-1893.

Joshi, K. R., Gavin, J. B. \& Armiger, L. C. (1975). Morphological identification of pathogenic yeasts using carbohydrate media. $J$ Bacteriol 123, 1139-1143.

Kohlhaw, G. B. \& Tan-Wilson, A. (1977). Carnitine acetyltransferase - candidate for transfer of acetyl-groups through the mitochondrial membrane of yeast. $J$ Bacteriol 129, 1159-1161.

Kozulic, B., Kappeli, O., Meussdoerffer, F. \& Fiechter, A. (1987). Characterization of a soluble carnitine acetyltransferase from Candida tropicalis. Eur J Biochem 168, 245-250.

McCourtie, J. \& Douglas, L. J. (1981). Relationship between cellsurface composition of Candida albicans and adherence to acrylic after growth on different carbon sources. Infect Immun 32, 1234 1241.

McCourtie, J. \& Douglas, L. J. (1985). Extracellular polymer of Candida albicans - isolation, analysis and role in adhesion. $J$ Gen Microbiol 131, 495-503.

Mannaerts, G. P. \& Van Veldhoven, P. P. (1990). The peroxisome - functional properties in health and disease. Biochem Soc Trans $\mathbf{1 8}$, 87-89.

Minnaert, K. (1961). Kinetics of cytochrome $c$ oxidase. I. The system: cytochrome $c$-cytochrome oxidase-oxygen. Biochim Biopbys Acta 50, 23-34.

Odds, F. C. (1988). Candida and Candidosis, 2nd edn, pp. 42-67. London: Baillière Tindall.

Okada, H., Ueda, M. \& Tanaka, A. (1986). Purification of peroxisomal malate synthase from alkane grown Candida tropicalis and some properties of the purified enzyme. Arch Microbiol 144, 137-141.

Osmani, S. A. \& Scrutton, M. C. (1983). The sub-cellular localization of pyruvate-carboxylase and of some other enzymes in Aspergillus nidulans. Eur J Biochem 133, 551-560.

Osumi, M., Fukuzumi, F., Yamada, N., Nagatani, T., Teranishi, Y., Tanaka, A. \& Fukui, S. (1975). Surface structure of some Candida yeast-cells grown on n-alkanes. J Ferment Tecbnol 53, 244-248.

Poulain, D., Cailliez, J. C. \& Dubremetz, J. F. (1989). Secretion of glycoproteins through the cell-wall of Candida albicans. Eur J Cell Biol 50, 94-99.

Prasad, R. (1985). Lipids in the structure and function of yeast membrane. Adv Lipid Res 21, 187-242.

Prasad, R. (1987). Nutrient transport in Candida albicans, a pathogenic yeast. Yeast 3, 209-211.

Rajasingham, K. C. \& Challacombe, S. J. (1988). Intracytoplasmic membrane configurations, vesicles and vesicular inclusions in Candida albicans. Cytobios 53, 7-17.

Ratledge, C. (1994). Biodegradation of oils, fats and fatty acids. In Biochemistry of Microbial Degradation, pp. 89-141. Edited by C. Ratledge. Dordrecht: Kluwer.

Ross, I. K., Debernardis, F., Emerson, G. W., Cassone, A. \& Sullivan, P. A. (1990). The secreted aspartate proteinase of Candida albicans - physiology of secretion and virulence of a proteinasedeficient mutant. J Gen Microbiol 136, 687-694.

Shepherd, M. G., Yin, C. Y., Ram, S. P. \& Sullivan, P. A. (1980). Germ tube induction in Candida albicans. Can J Microbiol 26, 21-26. 
Sheridan, R., Ratledge, C. \& Chalk, P. A. (1990). Pathways to acetyl-CoA formation in Candida albicans. FEMS Microbiol Lett 69, 165-169.

Srere, P. A., Jones, M. E. \& Matthews, C. K. (editors) (1990). Structural and Organisational Aspects of Metabolic Regulation (UCLA Symp Mol Cell Biol no. 133). New York: Wiley-Liss.

Sumegi, B., Sherry, A. \& Malloy, C. R. (1990). Channeling of TCA cycle intermediates in cultured Saccharomyces cerevisiae. Biochemistry 29, 9106-9110.

Tanaka, A. \& Fukui, S. (1989). Metabolism of n-alkanes. In The Yeasts, 2nd edn, vol. 3, pp. 261-287. Edited by A. H. Rose \& J. S. Harrison. London: Academic Press.

Tanaka, K., Kanbe, T. \& Kuroiwa, T. (1985). 3-Dimensional behavior of mitochondria during cell-division and germ tube formation in the dimorphic yeast Candida albicans. J Cell Sci 73, 207-220.

Tokunaga, M., Kusamichi, M. \& Koike, H. (1987). Ultrastructure of the inner cell-wall areas of Candida albicans. J Electron Microsc 36, 310 .

Ueda, M., Tanaka, A. \& Fukui, S. (1982). Peroxisomal and mitochondrial carnitine acetyltransferases in alkane-grown yeast Candida tropicalis. Eur J Biochem 124, 205-210.

Ueda, M., Tanaka, A. \& Fukui, S. (1985). Enhancement of carnitine acetyltransferase synthesis in alkane-grown cells and propionategrown cells of Candida tropicalis. Arch Microbiol 141, 29-31.
Vamecq, J. \& Draye, J-P. (1989). Pathophysiology of peroxisomal $\beta$ oxidation. Essays Biochem 24, 115-225.

Veenhuis, M. \& Harder, W. (1987). Metabolic sign and biogenesis of microbodies in yeasts. In Peroxisomes in Biology and Medicine, pp. 436-457. Edited by H. D. Fahimi \& H. Sies. Berlin \& Heidelberg: Springer-Verlag.

Veenhuis, M. \& Harder, W. (1991). Microbodies. In The Yeasts, 2nd edn, vol. 4, pp. 601-653. London: Academic Press.

WHO (1979). Problems related to the purification of Mycobacterium leprae from armadillo tissues and standardization of $M$. leprae preparation. In 1/79 of Report on the Enlarged Steering Committee Meeting, Geneva.

Yamamura, M., Teranishi, Y, Tanaka, A. \& Fukui, S. (1975). Preparation of protoplasts of hydrocarbon-utilizing yeast cells and their respiratory activities. Agric Biol Chem 39, 13-20.

Zlotnik, H., Fernandez, M. P., Bowers, B. \& Cabib, E. (1984). Saccharomyces cerevisiae mannoproteins form an external cell-wall layer that determines wall porosity. J Bacteriol 159, 1018-1026.

Zwart, K. B., Overmars, E. H. \& Harder, W. (1983). The role of peroxisomes in the metabolism of $\mathrm{D}$-alanine in the yeast Candida utilis. FEMS Microbiol Lett 19, 225-231.

Received 10 July 1996; accepted 16 July 1996. 